\title{
Als huiselijk geweld en georganiseerde misdaad samenkomen...
}

Citation for published version (APA):

Van Dooren, S., Janssen, J., Kolthoff, E., \& Vosters, N. (2019). Als huiselijk geweld en georganiseerde misdaad samenkomen... De weerbare professional op het grensvlak tussen strafrecht en hulpverlening. Proces: tijdschrift voor strafrechtpleging, 98(4), 258-269. https://doi.org/10.5553/PROCES/016500762019098004004

\section{DOI:}

10.5553/PROCES/016500762019098004004

Document status and date:

Published: 08/08/2019

Document Version:

Publisher's PDF, also known as Version of record

\section{Document license:}

CC BY-NC-ND

Please check the document version of this publication:

- A submitted manuscript is the version of the article upon submission and before peer-review. There can be important differences between the submitted version and the official published version of record. People interested in the research are advised to contact the author for the final version of the publication, or visit the DOI to the publisher's website.

- The final author version and the galley proof are versions of the publication after peer review.

- The final published version features the final layout of the paper including the volume, issue and page numbers.

Link to publication

\section{General rights}

Copyright and moral rights for the publications made accessible in the public portal are retained by the authors and/or other copyright owners and it is a condition of accessing publications that users recognise and abide by the legal requirements associated with these rights.

- Users may download and print one copy of any publication from the public portal for the purpose of private study or research.

- You may not further distribute the material or use it for any profit-making activity or commercial gain

- You may freely distribute the URL identifying the publication in the public portal.

If the publication is distributed under the terms of Article 25fa of the Dutch Copyright Act, indicated by the "Taverne" license above, please follow below link for the End User Agreement:

https://www.ou.nl/taverne-agreement

Take down policy

If you believe that this document breaches copyright please contact us at:

pure-support@ou.nl

providing details and we will investigate your claim.

Downloaded from https://research.ou.nl/ on date: 26 Apr. 2023 


\title{
Als huiselijk geweld en georganiseerde misdaad samenkomen...
}

\author{
De weerbare professional op het grensvlak tussen strafrecht en \\ hulpverlening*
}

Sylvia van Dooren, Janine Janssen, Emile Kolthoff \& Nanne Vosters

\section{Inleiding}

Ondanks het feit dat criminologen over elkaar buitelen op zoek naar een verklaring voor de almaar dalende criminaliteitscijfers, blijft toch ook het besef leven dat ondanks die neerwaartse lijn in de cijfers professionals in de veiligheidszorg nog steeds met tal van complexe problemen te maken hebben. De praktijk leert dat veiligheidsvraagstukken dikwijls zo lastig zijn aan te pakken omdat er verschillende soorten problemen tegelijk spelen, op elkaar inwerken en elkaar zelfs versterken. Zo zien bijvoorbeeld professionals in de hulpverlening aan betrokkenen bij allerhande vormen van geweld dat deze cliënten ook gebukt gaan onder zware schuldenproblematiek, ${ }^{1}$ of daarnaast familieleden hebben die met één been in de georganiseerde misdaad staan. ${ }^{2} \mathrm{Om}$ mensen die in dergelijk zwaar weer verzeild zijn geraakt daadwerkelijk goed te kunnen ondersteunen is het nodig dat professionals met gedegen kennis van al die specifieke onderliggende problemen goed samenwerken. ${ }^{3}$ Dat is makkelijk gezegd, maar is dat ook zo eenvoudig uit te voeren? Die vraag staat in deze bijdrage centraal. Wij richten ons hier specifiek op de vraag hoe samenwerking tussen professionals in het strafrecht en in de hulpverlening gestalte kan krijgen bij gezinnen waar zowel geweldsproblematiek als betrokkenheid bij georganiseerde misdaad speelt. De 'harde' en de 'zachte' kant van de veiligheidszorg komen bij de aanpak van zaken regelmatig samen. Er is met andere woorden casuïstiek waarbij aan de ene kant professionals uit de opsporing, handhaving en vervolging aan zet zijn, en aan de andere kant hulpver-

* Mr. Sylvia van Dooren is als docent verbonden aan de Juridische Hogeschool van Avans en Fontys en als onderzoeker aan het lectoraat Ondermijning van Avans Hogeschool. Prof. dr. Janine Janssen is hoofd onderzoek van het Landelijk Expertise Centrum Eer Gerelateerd Geweld van de Nationale Politie, lector Veiligheid in Afhankelijkheidsrelaties aan Avans Hogeschool, bijzonder hoogleraar Rechtsantropologie aan de Open Universiteit en voorzitter van de redactie van PROCES. Prof. dr. Emile Kolthoff is hoogleraar Criminologie aan de Open Universiteit en lector Ondermijning aan Avans Hogeschool. Nanne Vosters is als docent verbonden aan de deeltijdopleiding Social Work van Avans Hogeschool en als onderzoeker aan het lectoraat Veiligheid in Afhankelijkheidsrelaties van Avans Hogeschool.

1 F. Bekken, m.m.v. F. Kunseler \& A. van Dijke, Geld en geweld. Armoede en schulden in afhankelijkheidsrelaties, Amsterdam: SWP 2018.

2 J. Janssen, “Zij vreet er ook van.” Over de ongemakkelijke relatie tussen huiselijk geweld en zware en georganiseerde criminaliteit', Tijdschrift voor Criminologie 2019, 2, p. 203-212. Janssen 2019. 
leners uit het sociale domein. In theorie kan het zijn dat ze samenwerken, maar het is ook niet uitgesloten dat ze in elkaars vaarwater komen omdat ze een andere visie op het aan te pakken probleem hebben en uiteraard ook uit hoofde van hun functie andere rollen en taken dienen te vervullen. Een weerbare professional is idealiter in staat dit soort lastige situaties te hanteren. In deze bijdrage verstaan wij onder weerbaarheid van de professional dat deze in staat is om eigen grenzen te onderkennen en te bewaken en daarnaast niet onzeker wordt van tegenslag of moeilijkheden. Een weerbare professional blijft overeind als het lastig wordt. ${ }^{4}$

In de eerste paragraaf van deze bijdrage leggen we nog eens kort uit hoe complex huiselijk geweld is en welke factoren van invloed kunnen zijn op het ontstaan en voortbestaan van dit geweld. Hierbij besteden we ook aandacht aan de eventuele invloed van betrokkenheid van gezinsleden bij georganiseerde criminaliteit. In de tweede paragraaf is ons vertrekpunt de 'harde' kant van de veiligheidszorg. We nemen een kijkje in de wereld van de bijzondere opsporingsmethoden en vragen ons af hoe de inzet daarvan van invloed kan zijn op het ontstaan van geweld in huiselijke kring. In de derde paragraaf starten we aan de 'zachte' kant van de veiligheidszorg: hoe kijken hulpverleners aan tegen familieproblematiek waarbij ook een relatie met georganiseerde misdaad speelt? Tot slot vragen wij ons af wat onze verkenningen van beide kanten van de veiligheidszorg betekenen voor de weerbaarheid van de professional.

\section{Een ecologisch model voor huiselijk geweld}

\section{Frequentie}

Uit recent onderzoek ${ }^{5}$ blijkt dat ongeveer één op de twintig (5,5\%) volwassenen in vijf jaar tijd naar eigen zeggen wel eens met een voorval van fysiek en/of seksueel geweld in huiselijke kring te maken heeft gehad. ${ }^{6}$ Het gaat om $6,2 \%$ van de vrouwen en 4,7\% van de mannen. Dit zijn in totaal circa 747.000 mensen van 18 jaar of ouder. Zij zijn in de genoemde periode van vijf jaar slachtoffer geweest van minstens één incident dat werd gepleegd door iemand uit de brede huiselijke kring: van partner, ex-partner, andere gezins- en familieleden tot huisvrienden. Bij een derde (34\%) van deze mensen bleef het bij een eenmalig incident. Bij $41 \%$ kwam enkele malen een geweldsvoorval voor. Bijna $20 \%$ van de slachtoffers heeft structureel fysiek en/of seksueel huiselijk geweld meegemaakt; dat wil zeggen geweld dat maandelijks, wekelijks of dagelijks voorkwam. Het gaat hier om circa 97.000 vrouwen en circa 27.000 mannen.

4 E. Hooghiemstra \& L. Verharen, 'Professionals in een veranderd speelveld: van onwennigheid naar weerbaarheid', Jeugdbeleid. 2015, 4, p. 173-179.

5 A. ten Boom \& K. Wittebrood, De prevalentie van huiselijk geweld en kindermishandeling in Nederland, Den Haag: WODC 2019.

6 L. van Eijkern, R. Downes \& R. Veenstra, Slachtofferschap van huiselijk geweld: prevalentieonderzoek naar de omvang, aard, de gezinsachtergronden, de emotionele betekenis en de psychische en psychosomatische gevolgen, Den Haag: WODC 2018. 


\section{Verklaringen}

Op basis van deze cijfers is het niet te veel gezegd dat huiselijk geweld wijd verbreid is in onze samenleving. Het is niet alleen een veelvoorkomend verschijnsel, het is ook een verschijnsel waarop tal van verklaringen voor het ontstaan en voortbestaan van toepassing zijn. In de literatuur over huiselijk geweld wordt wel verwezen naar een 'ecologisch model', waarin relevante factoren uit verschillende theorieën en op verschillende niveaus worden onderscheiden, factoren die elkaar beïnvloeden. Zonder de pretentie te hebben volledig te zijn schetsen we een dergelijk model hier in vogelvlucht. Op het macroniveau van de samenleving speelt bijvoorbeeld de juridische context een rol: wat is wel en niet verboden? Denk in dit verband ook aan de politiek-bestuurlijke omgeving, waarin besluiten worden genomen over het al dan niet investeren in hulpverlening. En dan zijn er nog factoren als armoede, werkgelegenheid en genderverhoudingen. Op mesoniveau komen we op het niveau van huishoudens en families uit. Beschikken zij over een goed sociaal netwerk waar ze in geval van nood om hulp kunnen vragen? Welke opvattingen leven daar over het gebruik van geweld en genderverhoudingen? Zijn er financiële middelen en hoe wonen de mensen? Hoe gaan familieleden met elkaar om? Zijn er al onderling gewelddadige ervaringen opgedaan of zijn de onderlinge relaties stabiel en liefdevol? Op microniveau gaat het om het individu. Daar kunnen factoren als persoonlijke opvattingen over genderverhoudingen, eigen ervaringen met geweld, verslaving, (geestelijke) gezondheidsproblemen en/ of een delinquente levensstijl het ontstaan van geweld beïnvloeden. ${ }^{7}$

\section{Een opvallende omissie}

Wat ons opvalt in de brede literatuur over huiselijk geweld, is dat een delinquente levensstijl en/of verslaving als een factor van invloed wordt genoemd. ${ }^{8}$ We zien in die literatuur echter nauwelijks aandacht voor huiselijk geweld in kringen waarin georganiseerde criminaliteit een rol speelt. De vraag is of de vorm van delinquent gedrag in het algemeen en zware criminaliteit in het bijzonder niet ook een factor is die van invloed is op het ontstaan van geweld binnen de huiselijke kring. Daar komt nog bij dat bij zware vormen van criminaliteit door politie en justitie gebruik kan worden gemaakt van voor betrokkenen zeer ingrijpende opsporingsmethoden en dwangmiddelen. Dat gegeven intrigeert ons dermate dat het ons geïnspireerd heeft tot het schrijven van dit stuk. Want we zitten wel met een aantal belangrijke vragen: In hoeverre trekt het gebruikmaken door de overheid van die ingrijpende bevoegdheden een wissel op het leven van gezinnen en families? Hoe denken betrokken professionals aan de verschillende kanten van de veiligheidszorg over eventuele risico's? En wat heeft dat voor consequenties voor de samenwerking van verschillende professionals op het snijvlak van hulpverlening en opsporing, wat we hiervoor de 'zachte' en de 'harde' kant van de veiligheidszorg hebben genoemd?

In het nu volgende proberen we een tipje van de sluier op te lichten, waarbij we op voorhand aangeven dat ook wij niet met harde antwoorden gaan komen door dat

$7 \quad$ Ten Boom \& Wittebrood 2019.

$8 \quad$ Zie Ten Boom \& Wittebrood 2019. 
gebrek aan onderzoeksliteratuur. We proberen vooral aandacht te vragen voor mogelijke verbanden en factoren van invloed die verder aandacht en onderzoek behoeven.

\section{De harde kant van de veiligheidszorg}

\section{Doorwerking van bijzondere opsporingsmethoden in het gezinsleven}

'We zijn hier om ruis te veroorzaken, om te kijken wat er loskomt. Wat je wil is dat die vriendin naar haar vriend toe stapt en zegt: he idioot, meld je bij de politie. ${ }^{\prime 9}$ Dit citaat komt uit een interview met medewerkers van het team Werken Onder Dekmantel (WOD) en laat zien dat niet alleen verdachte burgers object van opsporing door de politie kunnen zijn. Ook niet-verdachte burgers zoals gezinsleden kunnen, al dan niet bewust, door de politie op verschillende manieren worden ingezet bij het werken onder dekmantel. Op deze wijze kan er worden binnengedrongen in het privéleven van de verdachte, maar dientengevolge wordt er ook binnengedrongen in het privéleven van familieleden of andere relaties van de verdachte. ${ }^{10}$

De politie heeft in het kader van de opsporing van strafbare feiten diverse bevoegdheden tot haar beschikking. Al deze opsporingsbevoegdheden dienen een wettelijke basis te hebben, maar hoe ingrijpender de bevoegdheid ingrijpt in het privéleven van de burgers, hoe specifieker deze opsporingsbevoegdheid in de wet moet zijn opgenomen. Zo biedt de taakstellende bevoegdheid van artikel 3 Politiewet ${ }^{11}$ een voldoende wettelijke basis voor opsporingsbevoegdheden die een beperkte inbreuk maken op het privéleven van de burger. Er zijn echter ook opsporingsbevoegdheden die een meer dan beperkte inbreuk maken op het privéleven van burgers. Een goed voorbeeld van deze opsporingsbevoegdheden zijn de bijzondere opsporingsbevoegdheden die zijn opgenomen in de Wet bijzondere opsporingsbevoegdheden (Wet BOB). Onder deze bijzondere opsporingsbevoegdheden vallen bijvoorbeeld infiltratie en het stelselmatig inwinnen van informatie.

Bij de inzet van (bijzondere) opsporingsbevoegdheden spelen de beginselen van proportionaliteit en subsidiariteit een belangrijke rol. Zo zal een BOB-middel slechts kunnen worden ingezet indien er evenredigheid bestaat tussen de ernst van het misdrijf en de ingrijpendheid van het ingezette middel, en daarnaast moet hetzelfde doel niet kunnen worden bereikt met minder ingrijpende middelen. ${ }^{12}$ De BOB-middelen kunnen niet worden ingezet zonder bevel van veelal de officier van justitie. Voor bijvoorbeeld infiltratie geldt een strenger toestemmingsvereiste, te weten een advies van de Centrale Toetsingscommissie. ${ }^{13}$ Het is

9 E. Stoker \& W. Thijssen, 'Waarom de politie onder dekmantel werkt', de Volkskrant 6 maart 2018.

10 S.L.M Janssen, 'De niet-verdachte burger in de opsporing', NJB 2015/544.

11 De politie heeft tot taak in ondergeschiktheid aan het bevoegd gezag en in overeenstemming met de geldende rechtsregels te zorgen voor de daadwerkelijke handhaving van de rechtsorde en het verlenen van hulp aan hen die deze behoeven.

12 E.W. Kruisbergen, Opsporen onder dekmantel, Den Haag: WODC 2010, p. 69.

13 Kruisbergen 2010, p. 54. 
natuurlijk belangrijk dat de wetgever rekening houdt met de proportionaliteit en de subsidiariteit, maar ons valt op dat we in de literatuur niet of nauwelijks aandacht vinden voor de manier waarop de inzet van de hier genoemde bevoegdheden doorwerkt op gezinsleden van subjecten van opsporing, en of deze doorwerking op het gezinsleven wordt meegenomen bij de vraag of en op welke wijze een bepaalde bijzondere opsporingsbevoegdheid moet worden ingezet.

\section{Stelselmatig inwinnen informatie in kring rondom verdachte}

Hoe zit dat dan als we gaan kijken naar de benadering van familieleden als bronnen van informatie? ${ }^{14}$ Bij deze bijzondere opsporingsbevoegdheid kan een opsporingsambtenaar stelselmatig in de omgeving van de verdachte verkeren en aan activiteiten of gesprekken deelnemen waar ook andere personen dan de verdachte aan deelnemen. ${ }^{15}$ Misleiding kan hierbij uiteraard ook een rol spelen. Dat deze kring rondom de verdachte de aandacht van de politie heeft, blijkt uit het recentelijk uitgebrachte rapport Betonrot. ${ }^{16}$ Zo kenmerken subculturen als de Outlaw Motorcycle Gangs (OMG's) zich door een geslotenheid voor buitenstaanders en een onderlinge loyaliteit. ${ }^{17}$ Deze geslotenheid maakt het moeilijk voor buitenstaanders om het netwerk zelf binnen te dringen waardoor de gezinsleden van de verdachte in beeld kunnen komen. De vrouwen en kinderen van de verdachten kunnen dienen als goede informatiebron om een breder zicht te verkrijgen op een netwerk. ${ }^{18}$ Bovendien hebben zij vaak weet van de criminele activiteiten van hun partners en vormen zij hierdoor een zwakke plek van de verdachten. ${ }^{19}$

Dat de politie vrouwen (en kinderen) als potentiële informatiebron ziet, blijkt ook uit een aantal recente en minder recente voorbeelden uit de jurisprudentie. Zo werd in een coldcasezaak het jonge gezin van de verdachte gebruikt als middel om informatie van deze verdachte los te krijgen. ${ }^{20}$ Hoewel de mannelijke en de vrouwelijke politie-informant werden geïnstrueerd om de contacten met de verdachte en zijn vriendin zo veel mogelijk zakelijk te houden, hebben deze contacten echter toch geleid tot een etentje bij de verdachte en zijn vriendin thuis en een kraambezoek nadat er gezinsuitbreiding had plaatsgevonden in het jonge gezin van de verdachte. Om geen argwaan te wekken zijn de informanten op deze uitnodiging ingegaan. Een dergelijke casus roept ethische vragen op. Hoewel de rechtbank oordeelde dat de bijzondere opsporingsbevoegdheden niet onrechtmatig waren ingezet en de verdachte een straf van vier jaar gevangenisstraf oplegde, is hier naar onze mening toch wel sprake van het oprekken van grenzen. De politieinformanten handelden in strijd met hun instructie om hun opdracht zo goed mogelijk ten einde te brengen. Aan de ene kant had de officier van justitie wel

B.F. Keulen e.a., Leerstukken strafrecht, Deventer: Kluwer 2016, p. 421.

A. van Wijk \& A. Lenders, Betonrot. Een kwalitatief onderzoek naar het fenomeen ondermijnende criminaliteit in Brabant-Zeeland, de effecten van en richtingen voor de overheidsaanpak, Arnhem: Bureau Beke 2018.

Van Wijk \& Lenders 2018, p. 17.

Van Wijk \& Lenders 2018, p. 58.

Van Wijk \& Lenders 2018, p. 57.

Rb. Amsterdam 22 april 2013, ECLI:NL: RBAMS:2013:BZ8826. 
toestemming gegeven voor dit optreden van de politie, maar van een afstand bezien doet dit toch ook denken in wat in de literatuur noble cause corruption wordt genoemd of, meer concreet, 'taakgerelateerd ongeoorloofd handelen' ${ }^{21}$ Het doel heiligt nu eenmaal niet de middelen.

Een ander recenter voorbeeld van het inschakelen van het gezin van de verdachte ten behoeve van het opsporingsonderzoek betrof de zogenoemde vergismoord op Djordy Latumahina, een Amsterdamse dj die het slachtoffer werd van een persoonsverwisseling. ${ }^{22}$ Teneinde in deze zaak de verdachte ertoe te bewegen om zich te melden bij de politie werd de (niet-verdachte) vriendin van één van de zes verdachten, terwijl zij haar kinderen in de auto had zitten, klemgereden door undercoveragenten die zich voordeden als leden van een motorclub. ${ }^{23}$ Hoewel de undercoveragenten geen colours van Satudarah droegen, werd wel de suggestie gewekt dat het hier ging om leden van een Molukse motorclub. Dit mede ook gezien de Molukse achtergrond van het slachtoffer, Latumahina. ${ }^{24}$ De vriendin van de verdachte dacht in ieder geval te maken te hebben met leden van Satudarah. De confrontatie met de motorclubleden leidde ertoe dat de vriendin haar vriend ertoe bewoog zich die avond nog te melden bij de politie. De verdachte werd uiteindelijk vrijgesproken van betrokkenheid bij de moord van Djordy Latumahina. Hoewel de inzet van undercoveragenten in deze zaak stof deed opwaaien, wordt door het team WOD over deze zaak aangegeven: 'Het gaat niet om de vraag of ze verantwoordelijk is, maar om wat ze mogelijk weet en of ze ons een haakje kan geven om de kluwen te ontwarren. ${ }^{25}$

\section{Ruisstrategie}

In de voornoemde vergismoord-zaak werd door de politie geprobeerd om ruis te veroorzaken en de politie past deze 'ruisstrategie' in meer zaken toe. Door de Hoge Raad is in een uitspraak van 9 januari 2018 aangegeven dat de ruisstrategie als opsporingsmethode is toegestaan. ${ }^{26}$ De ruisstrategie bestond er in deze zaak uit dat er onjuiste informatie aan verdachten was verstrekt door de politie over een fictieve buit. Gezien de beperkte inbreuk van deze ruisstrategie is de Hoge Raad van mening dat artikel 3 Politiewet een voldoende wettelijke basis biedt.

Dat deze ruisstrategie niet alleen in het leven van de verdachte, maar ook in dat van zijn gezinsleden kan ingrijpen, wordt geïllustreerd in de zogenoemde Oudejaarsmoord. ${ }^{27}$ In deze zaak werd, nadat de verdachte was vrijgesproken in de hoofdzaak, door zijn advocaat een artikel 12 Sv-procedure opgestart wegens

21 R. van Halderen \& E. Kolthoff, 'Noble Cause Corruption and Task-Related Rule-Breaking Behavior', in: A. Farazmand (red.), Global Encyclopedia of Public Administration, Public Policy, and Governance, Zwitserland: Springer International Publishing, p. 1-9, doi 10.1007/978-3-319-31816-5_2510-1.

22 P. Vugts, 'Zeer zware straffen voor liquidatie Djordy Latumahina', Het Parool 9 mei 2018.

23 Rb. Amsterdam 9 mei 2018, ECLI:NL:RBAMS:2018:3226.

24 E. Stoker, 'Agenten gingen undercover bij Molukse motorclub om bewijs te verzamelen in Amsterdamse vergismoord', de Volkskrant 28 november 2017.

25 Stoker \& Thijssen 2018.

26 HR 9 januari 2018, ECLI:NL:HR:2018:18.

27 Rb. Oost-Brabant 8 december 2016, ECLI:NL:RBOBR:2016:6805. 
bedreiging. Deze bedreiging zou hebben plaatsgevonden door de undercoveragenten die in de hoofdzaak waren ingezet. ${ }^{28}$ Hoewel het relaas van klager niet volledig uit de bewijsmiddelen blijkt, is de kern van deze aangifte dat twee agenten van het team WOD de ex-vriendin van klager hebben benaderd door haar thuis te bezoeken. Bij dit bezoek is aan de ex-vriendin medegedeeld dat verdachte een oplossing moest zoeken voor de schuld ad 50.000 euro die het vermoorde slachtoffer in de hoofdzaak had gehad. Wat er daarna is gebeurd, kan niet geheel aan de hand van bewijsmiddelen worden gestaafd. Volgens klager hebben de undercoveragenten hem in een later telefoongesprek aangegeven dat hij aan zijn vrouw en kinderen moest denken en dat er iets met hen zou gebeuren als hij niet zou betalen.

Hoewel de bewijsmiddelen de beweringen van klager en zijn ex-vriendin niet geheel staven, is het hof wel van mening dat het feit dat twee voor haar onbekende mannen aan de voordeur van de ex-vriendin van klager zijn verschenen en de voornoemde bewoordingen hebben geuit, zowel voor de ex-vriendin als voor de klager onder de gegeven omstandigheden als zeer bedreigend moeten zijn ervaren. Omdat het hof niet kon vaststellen aan de hand van bewijsstukken of er daadwerkelijk sprake was geweest van bedreiging, is het beklag van verdachte afgewezen. Het hof heeft echter wel aangegeven dat 'naar het oordeel van het hof de door het team WOD gevolgde werkwijze op het grensvlak van wat al dan niet als strafbaar handelen, in casu bedreiging c.q. afpersing, kan worden aangemerkt'. Een dergelijke redenering zou naar onze mening ook gelden voor de eerder besproken casus Latumahina. Ook daar ging de inbreuk op de persoonlijke levenssfeer veel verder dan ruis veroorzaken. De vraag rijst ook of dergelijke opsporingsmethoden niet op gespannen voet staan met artikel 8 van het Europees Verdrag voor de rechten van de mens (EVRM) (het recht op eerbiediging van privé-, familie- en gezinsleven) en voor wat betreft de verdachte met artikel 6 EVRM (het recht op een eerlijk proces).

\section{Stelselmatig inwinnen van informatie door burgers}

Niet alleen kan de politie zelf overgaan tot het stelselmatig inwinnen van informatie, maar zij kan hiertoe ook burgers inschakelen. Als deze inzet leidt tot een beperkte inbreuk op de privacy van de verdachte, biedt artikel 3 Politiewet hiertoe een voldoende basis. Vindt er echter een grotere privacyinbreuk plaats, dan dient de bevoegdheid te worden uitgeoefend op grond van artikel 126v Wetboek van Stafvordering (Sv). ${ }^{29}$ Dat het inschakelen van familieleden als informanten ernstige gevolgen kan hebben, bleek uit de uitspraak van het Hof Den Bosch van 29

29 In geval van verdenking van een misdrijf, dan wel in een geval als bedoeld in art. 126o lid 1, kan de officier van justitie in het belang van het onderzoek bevelen dat een opsporingsambtenaar met een persoon die geen opsporingsambtenaar is, overeenkomt dat deze voor de duur van het bevel bijstand verleent aan de opsporing door stelselmatig informatie in te winnen omtrent een verdachte, onderscheidenlijk een persoon ten aanzien van wie een redelijk vermoeden bestaat dat deze is betrokken bij het in het georganiseerd verband beramen of plegen van misdrijven. Zie ook E. Bleichrodt \& E. Moerman, 'Enkele vormen van private bijdragen aan de opsporing belicht', Ars Aequi 2013, juli/augustus. 
januari 2016 in een zaak waarbij de ex-vriendin van de verdachte vermoedelijk werd ingeschakeld om informatie in te winnen inzake de criminele activiteiten van haar voormalige vriend. ${ }^{30}$

In deze zaak heeft de ex-vriendin van de verdachte de politie gemeld dat haar vriend zich in het criminele circuit bevond en een hennepkwekerij had. De exvriendin en haar vriend hadden samen een kind, en de ex-vriendin wilde de omgangsregeling stopzetten gezien de criminele contacten van verdachte. De exvriendin heeft op enig moment in de procedure een verklaring bij de rechter-commissaris afgelegd waarin zij heeft aangegeven dat zij samen met de politie bezig is geweest om bewijzen te verzamelen tegen haar vriend. De politie had haar, volgens de ex-vriendin, hierbij aangegeven: 'jij helpt ons en wij helpen jou'. Ook had de politie de ex-vriendin verteld dat zij bewijzen kon verzamelen door het maken van foto's en opnames. Tevens werd aangegeven dat zij haar ex-partner kon volgen. De ex-vriendin had hierbij de indruk dat de politie vooral geïnteresseerd was in de hennepteelt. In een latere verklaring bij de rechter-commissaris is de ex-vriendin echter teruggekomen op haar verklaring en heeft zij aangegeven dat zij de bewijzen tegen haar ex op haar eigen initiatief heeft verzameld. Twee maanden na deze laatste verklaring is zij doodgeschoten voor haar appartement. $^{31}$

Het hof is van mening dat uit de bewijsstukken blijkt dat er sterke aanwijzingen aanwezig zijn dat de politie de ex-vriendin van de verdachte ertoe heeft aangezet bijstand te verlenen aan de opsporing door stelselmatig informatie in te winnen omtrent haar ex-partner. Hier lag echter geen bevel van de officier van justitie ex artikel $126 \mathrm{v}$ Sv aan ten grondslag. Bovendien is er niets van deze bijstand vastgelegd in mutaties of processen-verbaal. De politie heeft hier ook geen openheid van zaken over gegeven in de diverse getuigenverhoren die hebben plaatsgevonden. Aangezien de door de politie gehanteerde methode ernstig heeft ingegrepen in de persoonlijke levenssfeer van de verdachte (het betrof zijn ex-vriendin, met wie hij een kind had en die bewijs tegen hem heeft verzameld), en er geen processen-verbaal zijn opgesteld, is er sprake van een dermate ernstig vormverzuim dat het Openbaar Ministerie in deze zaak niet-ontvankelijk is verklaard.

Met de hier gegeven voorbeelden uit de jurisprudentie hebben wij duidelijk willen maken dat (niet verdachte) familieleden van een verdachte binnen de opsporing kunnen worden ingezet als informatiebron. Deze inzet van familieleden als informatiebron kan binnen het gezin leiden tot stress. En stress is een factor die invloed kan hebben op het ontstaan van geweld. We zijn de eersten om toe te geven dat we hier geen hard verband met huiselijk geweld hebben gepresenteerd. De voorafgaande uitwerking van de impact van de inzet van bepaalde bevoegdheden en strategieën kan onzes inziens echter wel van invloed zijn op het ontstaan van huiselijk geweld. We zouden het in ieder geval toejuichen als hier in de prak-

30 Hof Den Bosch 29 januari 2016, ECLI:NL:GHSHE:2016:242.

31 Deze moord is nog altijd niet opgelost en staat op de Brabantse coldcasekalender 2019. De expartner heeft een alibi en andere verdachten zijn wegens gebrek aan bewijs weer vrijgelaten. Het motief voor de moord is nog altijd onduidelijk. www.bd.nl/oss-e-o/van-bosch-babylijkje-totmogelijke-wraak-op-tamara-plehn-7-brabantse-zaken-op-nieuwe-coldcasekalender a7c82165/. 
tijk meer aandacht voor zou zijn en als dit thema ook serieus onderwerp van onderzoek zou worden.

\section{De zachte kant van de veiligheidszorg}

\section{Onduidelijkheid}

Hiervoor is al aangegeven dat we relatief weinig aandacht zien voor de overlap tussen huiselijk geweld en georganiseerde misdaad. Dat wil niet zeggen dat die er helemaal niet is. ${ }^{32}$ Op het gebied van mensenhandel is bijvoorbeeld aandacht gevraagd voor het feit dat deze vorm van zware criminaliteit zich ook in de familiekring manifesteert. ${ }^{33}$ Daarbij wordt ook een beroep gedaan op emotionele banden in de familie en concepten als familie-eer. ${ }^{34}$ Ook aan de al eerdergenoemde OMG's in relatie tot het gezinsleven is al eens op bescheiden wijze aandacht besteed. ${ }^{35}$ Daar waar er specifiek op samenloop van huiselijk geweld en georganiseerde criminaliteit wordt ingegaan, blijkt dat er in de praktijk veel onduidelijkheden leven. Zo vertelde een manager in een opvanginstelling voor huiselijk geweld ooit: 'In al die gevallen die ik gezien heb, gaat het om huiselijk geweld. Het feit dat die man lid is van een club maakt het moeilijker om weg te gaan. Wat ik vooral hoor is dat vrouwen bang zijn om weg te gaan omdat ze er beducht op zijn dat de club ze dan gaat zoeken. Hoe reëel die angst is, durf ik niet te zeggen. Ik krijg de indruk dat het vaak iets is, waar zo'n man mee schermt, dat-ie veel vrienden heeft en zo. Maar of de kameraden van die club ook daadwerkelijk van zo'n dreigement op de hoogte zijn en daar achter staan, daar heb ik werkelijk geen idee van.'36

\section{Doorvragen}

Om meer duidelijkheid te krijgen loopt bij het lectoraat Veiligheid in Afhankelijkheidsrelaties van Avans Hogeschool een onderzoek naar vrouwen in opvanginstellingen van wie de (ex-)partner gelieerd is aan een OMG. Hoewel het onderzoek zich in een afrondende fase bevindt, is het prematuur om nu al met conclusies te komen. Desalniettemin willen we graag een tipje van de sluier oplichten. In theorie zijn er verschillende verbanden denkbaar tussen het gegeven dat een vrouw in de opvang terechtkomt en een (ex-)partner gelieerd is aan een OMG: de reden waarom een vrouw in een opvanginstelling belandt, heeft geen enkele relatie met de betrokkenheid van de (ex-)partner bij een OMG; er is een directe relatie, in die

32 Zie de pilot 'criminele families in Amsterdam', www.amsterdam.nl/wonen-leefomgeving/ veiligheid/criminele-families/.

33 C.E. Dettmeijer, L.B. Esser \& F. Noteboom, Zicht op kwetsbaarheid. Een verkennend onderzoek naar de kwetsbaarheid van kinderen voor mensenhandel, Den Haag: Nationaal Rapporteur Mensenhandel en Seksueel Geweld tegen Kinderen 2016.

34 M. Verhoeven, Government Policies and Sex Work Realities: Human Trafficking in the Regulated Sex Industry, Amsterdam: Vrije Universiteit 2017; J. Janssen \& M. Rasenberg, 'Dangerous liaisons. Over de relatie tussen mensenhandel en eergerelateerd geweld', PROCES 2017, 6, p. 438-447.

35 Zie bijv. E.C. Ulloa, R.B. Dyson \& D.D. Wynes, 'Inter-partner violence in the context of gangs: A review', Aggression and Violent Behavior 2012, 17, p. 397-404.

36 J. Janssen, 'Geweld achter de voordeur bij leden van 1\% motorclubs', Tijdschrift voor de Politie 2015,8 , p. 36. 
zin dat de vrouw zelf in conflict is met de club; of er is sprake van een indirecte relatie, in die zin dat er sprake is van een conflict in huiselijke kring waarbij de (ex-)partner schermt met zijn betrokkenheid bij een OMG om druk uit te oefenen. Uiteraard kan iemand ook angst hebben voor de betrokkenheid van de OMG, terwijl er feitelijk niets aan de hand is wat dat betreft. Doel van het onderzoek is vooral om na te gaan wat professionals in opvanginstellingen voor inzicht in deze samenloop hebben. Ook willen wij weten hoe zij hiermee omgaan. We hebben met medewerkers in de opvang gesproken, onder anderen met medewerkers van opvangmodaliteiten voor mensen die ernstig bedreigd worden. Bij de gespreksverslagen die aan respondenten zijn voorgelegd, viel ons op dat regelmatig het rode potlood rigoureus gehanteerd werd. Hoewel uiteraard door de onderzoekers anonimisering van de gegevens in het uiteindelijke onderzoeksverslag was toegezegd, wezen de respondenten niet alleen met klem op kenmerken van de individuele levensloop van betrokkenen bij de casuïstiek die zij als voorbeeld hadden genoemd, ook aspecten van de beveiliging werden expliciet benoemd. Men vreesde voor de veiligheid van de cliënten die aan hun zorg waren toevertrouwd.

Dan zou je denken dat deze professionals ook expliciete ideeën en inzichten hebben over de relatie tussen het lidmaatschap van een OMG en de problemen thuis achter de voordeur. Uit de aan ons gepresenteerde voorbeelden komen we in feite verschillende verbanden tegen. Er zaten gradaties in de betrokkenheid van de mannen bij de OMG en ook in de overlap van het sociale netwerk van de mannen en de vrouwen. Het kwam voor dat de sociale leefwereld van beiden grotendeels bestond uit contacten gelieerd aan de club. Daarnaast waren er ook situaties waarin de leefwereld van de mannen en de vrouwen relatief gescheiden was. Dan konden spanningen in de club zich overigens ook wel in de vorm van stress en geweld aan het thuisfront manifesteren.

\section{Dilemma's voor de hulpverlener}

Wat in het oog sprong was dat we ook wel eens vernamen dat een professional eigenlijk liever niets, of in ieder geval niet te veel wilde weten over de motorclub. Dat zou immers informatie kunnen zijn die ook voor de politie interessant is. Er wordt een spanningsveld gevoeld tussen hulpverlening en strafrecht en de complexiteit van de samenwerking tussen beide disciplines, wat we duidelijk maken aan de hand van situaties rondom huiselijk geweld en betrokkenheid bij een motorclub. Het is bekend dat de vrouwen vaak kennis hebben van eventuele criminele activiteiten van de club, dat ze zelf soms een rol spelen bij deze activiteiten en dat ze daarnaast regelmatig getuige en/of slachtoffer van geweld zijn. ${ }^{37}$ In deze situatie is het niet ondenkbaar dat gebruik wordt gemaakt van de hiervoor genoemde vormen van inwinnen van informatie.

Kennis van de betrokkenheid van de vrouw bij criminele activiteiten zorgt voor een hulpverlener zoals de sociaal werker voor moeilijke situaties. Niet alleen moet er een keuze gemaakt worden in het wel of niet betrekken van de politie om de veiligheid van de vrouw en eventuele kinderen te garanderen, ook moet afgewo-

37 C. Hopper \& J. Moore, 'Women in outlaw motor cycle gangs', Journal of Contemporary Ethnography 1990, 4, p. 363-387. 
gen worden welke - en in hoeverre - illegale activiteiten gemeld moeten worden. Als er tevens sprake is van vermoedens van kindermishandeling, moet ook hier volgens de Meldcode naar gehandeld worden. Het is ook niet ondenkbaar dat een melding bij Veilig Thuis meer kwaad dan goed doet als er onvoldoende oog is voor de complexiteit van de situatie waarin het gezin zich bevindt. ${ }^{38}$ Anderzijds dient een sociaal werker zorgvuldig om te gaan met vertrouwelijke informatie en moet hij de autonomie van de cliënt respecteren.

Vrouwen die zowel slachtoffer als dader zijn, worden daarnaast vaak niet geloofd door de politie. Deze vrouwen worden gezien als een deel van het probleem in plaats van als een deel van de oplossing. Zij zijn als het ware guilty by association. ${ }^{39}$ In dergelijke gevallen ziet de politie de vrouw soms meer als bron van informatie dan als slachtoffer van huiselijk geweld. Vrouwen zijn zich vaak zeer bewust van deze situatie. Dit wantrouwen naar de politie zorgt er vervolgens voor dat vrouwen vaak aan geen enkele professional volledige informatie geven, omdat deze informatie hen ook dubbel kwetsbaar maakt: de politie ziet hen als onderdeel van het aan te pakken criminaliteitsprobleem en binnen hun sociale omgeving lopen zij het risico op sancties en vergelding vanwege het praten met de politie. Dit heeft weer als gevolg dat de sociaal werker geen volledig en goed beeld krijgt van de situatie en bijbehorende gevaren, dat hij lastig een werkrelatie met de cliënt kan opbouwen en dat het niet altijd lukt om een positieve samenwerking met de politie van de grond te krijgen. Daarnaast is het voor de hulpverleners ook geen primair doel om een OMG aan te pakken. Een ander dilemma waar hulpverleners zich tegenwoordig voor geplaatst zien, is dat de overheid ook bij de aanpak van huiselijk geweld verwacht dat het vermogen tot zelfredzaamheid van burgers wordt aangesproken. Er is ook een trend waarneembaar naar meer ambulantisering en minder intramurale hulp. ${ }^{40}$ Het gaat erom dat het eigen sociale netwerk in stelling wordt gebracht. Maar hoe moet dat als de geweldsproblemen zich juist in die kring afspelen? ${ }^{41}$

\section{Tot slot: de weerbare professional}

\section{Twee punten}

In het voorafgaande hebben we twee punten duidelijk willen maken. In de eerste plaats dat er weliswaar gebrekkige aandacht is voor de overlap tussen huiselijk geweld en georganiseerde criminaliteit, maar dat we wel wat weten. Zo laat jurisprudentie zien dat familieleden als informatiebron kunnen en worden ingezet, maar ook als informant kunnen worden gebruikt. Deze belangen van familieleden

L. Cooper \&M. Bowden, 'Working with women associated with bikie gangs: practice Dilemmas', Australian Social Work 2006, 3, p. 301-313.

39 Janssen 2019.

40 J. Janssen \& B. Janssen, Ambulante hulpverlening en/of intramurale zorg? Een verkenning van beoordelingscriteria en randvoorwaarden voor de keuze voor ambulante in plaats van intramurale hulpverlening, Den Bosch: Expertisecentrum Veiligheid, Avans Hogeschool in opdracht van de Vereniging Nederlandse Gemeenten 2017.

41 J. Janssen, 'Bij geweld in afhankelijkheidsrelaties: Grenzen aan zelfredzaamheid', Vakblad Sociaal Werk 2018, 2, p. 23-25. 
zouden echter wel nadrukkelijker naar voren moeten komen in de proportionaliteits- en subsidiariteitstoets die door de officier van justitie wordt uitgevoerd. Dit aangezien het betrekken van familieleden in een WOD-traject tot risico's voor deze familieleden kan leiden. Zo kan de ruisstrategie tot stress en angst in het gezin leiden omdat er valse informatie wordt verspreid. Het 'lekken' van informatie aan een informant door een gezinslid kan eveneens tot stress en mogelijke represailles leiden. Het inzetten van een familielid als informant kan nog grotere risico's met zich brengen. Dat brengt ons in de tweede plaats bij de ethische dilemma's. Aan de 'harde' kant van de veiligheidszorg ligt begrijpelijkerwijs een zwaar accent op het opsporen van strafbare zaken. In het deel van deze bijdrage dat vanuit het perspectief van de 'zachte kant' in de veiligheidszorg, de hulpverlening, is geschreven, wordt eveneens aangegeven dat familieleden voor autoriteiten een interessante bron van informatie kunnen zijn. Vanuit het perspectief van de hulpverlening leven in dit verband ethische vragen over samenwerking met de autoriteiten en eventuele risico's die dat met zich kan brengen voor de vertrouwensrelatie met de cliënt en de verdere behandeling van de casus.

\section{Consequenties voor de weerbaarheid van de professional}

In het begin van deze bijdrage is de weerbaarheid van de professional omschreven als het vermogen om eigen grenzen te onderkennen en te bewaken en daarnaast niet onzeker te worden van tegenslag of moeilijkheden. Problematisch in dit verband is echter het gegeven dat er relatief weinig aandacht is voor de overlap tussen geweld achter de voordeur en vormen van georganiseerde misdaad. En dat geldt dus voor meer vormen van ondermijnende criminaliteit die gebruikmaken van het privédomein van burgers. Denk bijvoorbeeld aan vrouwen die in de opvang belanden na een conflict met hun partner over de wietplantage die deze op zolder heeft en de druk die daarop wordt gezet door misdaadondernemingen. Of aan de sociaal werker die in het kader van de Wet maatschappelijke ondersteuning een bezoek brengt aan een cliënt en signalen opvangt van ernstige criminaliteit. Er is weinig oog voor eventuele spanningen en ethische dillema's bij de aanpak van deze overlap en samenwerking daarbij in de veiligheidszorg. Wij stellen ons voor dat het expliciet benoemen van deze dillema's in een dialoog met de samenwerkingspartners uiteindelijk bij zal dragen aan inzicht in en consequenties voor professioneel handelen, alsmede aan het vermijden van onzekerheden en nog weerbaarder maken van professionals. 